\title{
Proposing an Indigenous Nigerian Folktale Therapy as a Counselling Model for Character Training and Behaviour Change among School Children
}

\author{
Emmanuel A. Adeoye ${ }^{1}$, Adegoke Olayinka Okeowo ${ }^{2}$, Adeoti Florence Yusuf ${ }^{3}$, Ogidan \\ Rotimi $^{4} *$
}

\section{(C) Uganda Martyrs University}

\begin{abstract}
Using the Yoruba race of Nigeria as fulcrum for the study, this paper examines the universality and didactic significance of archetypes in African folklore. The authors contend that Africa folklore, by virtue of its highly moralizing and didactic elements made possible by an embedded commonality of instructive archetypes, offers a lifeline that counsellors and psychologists can use in combating the moral decay in the Nigerian society. Based on this premise the paper goes on to present a counselling model for character training and behaviour change through the use of an indigenous Nigerian Folktale Therapy (I.N.F.T). The model is a response to the needed paradigm shift in the counterproductive traditional punitive method of combating undesirable behaviours that seem to have become rampant currently in Nigerian society. This model could indeed serve as springboard for adaptation in other African settings which are very rich in folklores.
\end{abstract}

Keywords $\cdot$ Folktale $\cdot$ Therapy $\cdot$ Counselling psychology

\section{Introduction}

There is no doubt that the Nigerian society is undergoing a period of what could best be described as a moral crisis. There is endemic corruption and moral decay across the land. Despite the embarrassing stigma of being labelled as the third most corrupt country $m$ the world by Transparency International, nobody seems to be able to do anything about it. The Guidance Counsellor, by virtue of his training, must be sensitive to events around him, and

\footnotetext{
${ }^{1}$ University of Ilorin

${ }^{2}$ Federal College of Education, Okene

${ }^{3}$ Osun State University

${ }^{4}$ National Open University of Nigeria, *Corresponding author: rjogidan@gmail.com
} 
take the bull by the horns where need be. This is one such time when these authors strongly believe that going back to the roots to employ the use of indigenous African folklore in addressing our social ills can produce remarkable results.

According to Nwosu (I980), African traditional and oral literature is a synthesis of such literary resources as folktales, stories, proverbs, riddles and poetry which are often inseparable as narratives or oral art. In the Yoruba traditional and contemporary society for instance, the desire to teach a child good habits starts early. Alamu (1997) asserted that, because of the moral, cultural and entertainment values inherent in them, children are exposed to tales to mould their characters right from youth, thereby laying solid foundations for their future. In Yoruba land, principles of good character in all its ramifications have their basis in Yoruba traditional education. Traditional education embraces Yoruba maxims that are needed for the building of children's moral and spiritual personality.

Indeed, the didactic purpose of folklore is achieved during narration as the themes are carefully selected (mainly involving an exposition of some vices) and the resultant punishment meted out to the perpetrator. The condemnation of vice and the reward of virtue as evidenced in the folktale are to teach children that there is reward in doing well. Mapanje and White (1983) observed that African achievements in moral literature include changeless and continuity in stories passed from generation to generation, in customs and community sayings preserved by the elders, the whole making up a culture of the kind celebrated so vividly in Chinua Achebe's Things Fall apart. A few decades ago when folktales were still told to children on moon-lit nights by parents and grandparents, such times always availed the parents the opportunity to inculcate virtues in the children. Such lessons and codes of conduct learnt were never lost on the listeners because of the informal setting and the high entertainment value of the stories. Equally, a wide variety of oral poetry addressed various aspects of the people's lives and activities. Praise poems do not only deal with chiefs and kings, but with any person in the community who could be praised for his diligence, skill, bravery, etc. There are also poems condemning all sorts of social vices. Traditional oral literature often offers a rich reservoir from which modern .writers could draw inspiration and materials in writing good, didactic literature for youths.

But the question is. In this modern age, how much of traditional folklore are the children and youths exposed to, any longer; Indeed moonlight stories are fast disappearing from our lexicon due to the invention of electricity. To compound this, parents hardly have time to sit their children down in semi-circle and tell folktales any more in this age of increasing percentage of career parents who are hardly found at home. So, all through his developmental years, the Nigerian child graduates by stages from watching 'Super Ted', "Spider Man', to watching war films and several un-edifying home videos, all of which are violence-based. Obviously, this does not augur well for the moral training of Nigerian children.

Although some moralistic songs, recitations and reactions, do feature in the corpus of Yoruba children's folklore and have found a permanent place in schools, it cannot replace the psycho-dramatic, affective-didactic imprint on the psyche of the young ones, achieved during the participatory involvement of the children in the stories. Of all vices, the Yoruba appear to abhor stealing most. This is exemplified in the song below. 
YORUBA

Kini ngo fo !e se

Laye ti mo wa/2ce

Laye ti mo wa

Laye ti mo wa

Kaka ki njale

Kaka ki njale

Ma kuku deru

Ktni ngo f'o lese

Laye ti mo wa
ENGLISH

What will drive me to steal?

In this world I have come into.

In this world I have come into

In this world I have come into

Instead of going to steal

Instead of going to steal

I would rather become a slave

What will drive me to steal?

In this world I have come into'

Here is another verse/ song that mocks and rebukes truancy in schools.

$\begin{array}{ll}\text { Solo: } & \text { Isa-n-sa mo tun de } 0 \\ \text { Chorus: } & \text { A le e ko lo, ko le io } \\ \text { Solo; } & \text { Isa-n-sa mo tun de O } \\ \text { Chorus; } & \text { A le e ko lo, ko le to } \\ \text { TRANSLATION } & \\ \text { Solo: } & \text { The truant Ishere again } \\ \text { Chorus: } & \text { We sent him away but he wouldn't go } \\ \text { Solo: } & \text { The truant is here again } \\ \text { Chorus } & \text { We sent him away but he wouldn't go }\end{array}$

This song, usually sung with clapping and dancing while peer group boos and jeers at the culprit, is found to be generally effective, as no child that had been so disgraced would like to repeat the behaviour.

The Gbayi, known and called 'Gwari' by others-a derogatory name which connotes paganism, today occupy several locations especially in the North Central part of Nigeria. They are found mainly in the Gwaris Federation of Minna division and also In Abuja area. The following tale reflects the dominant cultural values of patience, hard work and perseverance among them.

The wasp went to the bees to learn how to make honey (honey,-as we know, is a very valuable syrup). The bees obliged the wasp. However, the wasp could only manage to stay long enough to know how to make combs before returning home, Back home; the wasp could not of course, make honey. Neither could he tolerate jokes poked at him by his friends and neighbours. He would sting anyone who as much as came close to his comb. The wasp still does that to this day. Okeowo (2005) contends that this story can be very profitably used in inculcating the aforementioned values in lazy, indolent, or easily discouraged children.

\section{Significance of Archetypes}

The didactic and moralizing potentials in African folklore are enhanced by the presence of archetypes therein. In the words of Davis (1997) an archetypes is a recurring pattern of character, symbol, or situation found in the mythology, religion, and stories of all cultures. Carl Jung, a well-known neo-Freudian psychologist, found archetypal patterns and images in every culture and in every time period of human history. They behaved according to the 
same laws in all cases. He postulated the universal unconscious to account for this fact. He postulated that humans do not have separate, personal unconscious minds. Rather, they share a single universal unconscious mind rooted in the unconscious just as a tree is rooted to the ground. He also identified four archetypes-the mother archetype, the rebirth archetypes, the spirit archetype and the trickster archetype.

The tortoise, for instance, is a popular trickster figure in African folktales. He is known as Nnabe in Igbo culture, Fudugazi in Zulu culture and ijapa in Yoruba culture. Tortoise is physically slow but quick-witted, lives long time and has a long memory, and gains a type of wisdom by studying fellow creatures in society. But like trickster figures in the folklore of many world cultures, tortoise misuses his knowledge.

He is cunning and malicious, and dupes or tricks others for his own greed or selfish gain. According to Badejo's (1988) interpretation, the African tricksters like Yoruba ijapaperceive, remember, and study others "weaknesses in order to use this knowledge for the tricksters' own self-interest or amusement, or to escape social responsibilities. Tricksters exist on the peripheries of the social order. Their Individualistic, non-conformist behaviour, creates havoc and disharmony in society and can threaten the survival of the community.

Ugorji (1991) points out that the secular tricksters such as the Tortoise often project the kinds of evil force and bad behaviours against which the human community must contend to survive and which must be kept in check. This goal is rehearsed and achieved and which must be kept in check. This goal is rehearsed and achieved in the communal performances of African proverbs and folktales; herein the tricksters' bad, anti-social behaviours are usually punished and the evil forces unleashed are controlled or defeated. Thus, for example, recounting Tortoise stories in African communities can function to reaffirm the priority and wisdom of the community, reassure its members that balances and harmony can and should be restored, and that the community will survive and prevail.

There is in Ghana a story-telling art called Anansesem by Akan speaking people. The name, which literally means Ananse (spider) stories is used both for the body of stories and for the story-telling performance itself. Although story-telling is usually a domestic activity, there are in existence some specialist groups who have given it a full theatrical ${ }^{1}$ expression with established conventions.

Who is Ananse and why stories, so many stones be told about him? According to Sutherland (1999), Ananse appears to represent a kind of everyman artistically exaggerated and distorted to serve society as a medium for self-examination. He has a penetrating awareness of the nature and psychology of human beings and animals. He is also made to mirror in his behaviour fundamental human passions, ambitions and follies as revealed in contemporary situations. Significantly, laughter is the main social response to Ananse as a character. In addition, it is in the verbal comments which often underscore the laughter that society's attitude to him is clarified. Of these the most representative is 'Ananse's wealth!' A sarcastic expression for successes and triumphs, which are not likely to last. Indeed most of Ananse's successes are doubtful and temporary. By constantly overreaching himself he ruins his schemes and ends up impoverished. That Ananse is, artistically, a medium for society to criticize itself and can be seen in the expression, 'exterminate Ananse, and society will be ruined'.

The foregoing is insightful in appreciating the fact that African folklore, in which profoundly significant archetypes are embedded, serves important social and ethical purposes. More importantly, the element of universality In archetypes as reflected in 
African folktales In particular, makes folktales a useful avenue through which morality and ethical consciousness of the African, and more particularly Nigerian society can be salvaged.

\section{The Indigenous Nigerian Folktale Therapy (I.N.F.T, )}

"The I. N. F. T., developed by Okeowo (2006) is a treatment package of carefully selected folktales designed and developed to help in combating delinquent traits such as excessive greed, cheating, stealing, indolence, disobedience/stubbornness, bullying/aggressiveness in children.

The package may be better used in group counselling Involving clients of moderate delinquency, over a period of 8 to 10 counselling sessions spread over a time frame of 4 to 5 weeks. A longer time frame may be considered necessary at the discretion of the counsellor depending on availability of time, post-test readiness of group, etc.

\section{Model}

A model is an abstraction that is operationalised or made a reality by the use of the clinical psychotherapeutic process of assessment, diagnosis, treatment, evaluation and follow-up. According to Miquaii and Windahs (1993), a model is a consciously amplified description in graphic form of a piece of reality; and seeks to show the main elements of any structure or process and the relationship between these elements.

To this end, the conceptual model proposed in this paper is based on the Stimulus Organisms Response (SOR) model of the Behavioural Modifications Therapy (fig 1). It comprises an Independent, therapeutic variable i.e. Indigenous Nigerian Folktale Therapy (I.N.F.T), dependent variables, and intervening variables. The I.N.F.T., which is the independent variable, is manipulated. It is introduced in the form of a treatment package which will be administered on a set of Juvenile delinquents, through series of counselling sessions. The expected outcome is a behavioural change manifesting in the following dependent variables-positive self concept, improved interpersonal relationships with peers and significant others, improved academic and social activities, significant reduction in antisocial/delinquent habits and enhanced self esteem.

However, In-between the period of treatment and the expected outcome in the subjects of study are extraneous variables. These are characteristics or factors which cannot be measured directly, but which sometimes have an important effect on the behavioural outcome. All the variables (i.e. independent, intervening and dependent) are linked as shown in the model in Figure 1. 


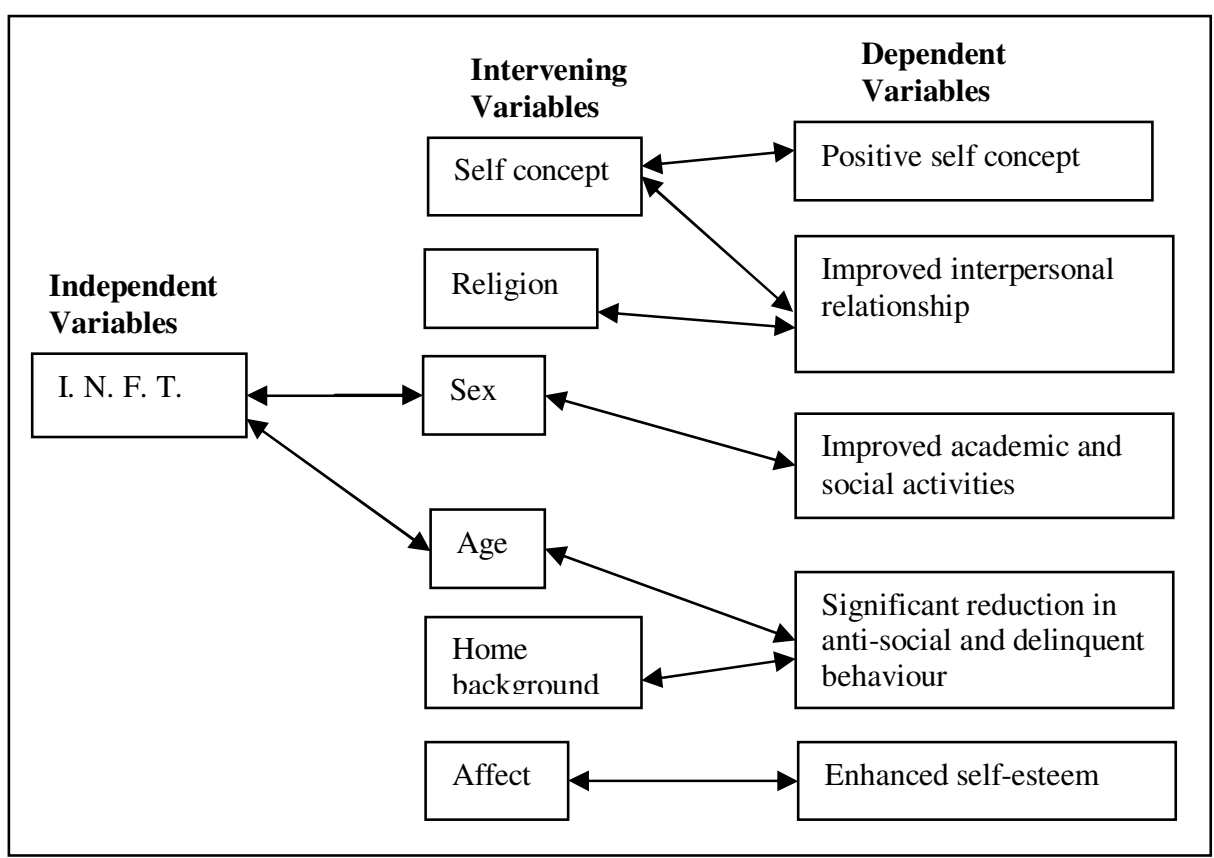

Figure 1: Counselling Model for Character Training and Behavioural Change Source: Adapted from Kanfer and Phillips (1970)

\section{Counsellor's Role}

The counselling technique should be leader-structured. The counsellor is to employ, the use of psychodrama during the sessions. He should provide an ideal story-telling environment with plenty of space for modelling, role-play etc. The setting should also be as close to nature (flora/fauna) as possible. The counsellor should be focused and remain guided by the instructions and procedure in the I. N. F. T package.

\section{Implications for Counselling}

Guidance counsellors, sociologists, psychologists and significant others will find indigenous Africa folktales very helpful in redirecting the value orientation of children and youths, and generally alleviating the moral decay in the society. Adeoye, $\{2000\}$ noted that excessive dependent on traditional punitive measures to curb undesirable behaviours in schools have been found to become counterproductive. Hence, a paradigm shift in methodology becomes necessary and I. N. F. T. has been found to be appropriate in this regard, \{Okeowo 2006\}, Furthermore, Piaget $\{1988\}$, noted all affective behaviour have a cognitive base. It follows that appropriate and goal-directed folktales can be used to channel me - minds of children towards good citizenship. This, it is hoped, will also help $\mathrm{m}$ checking the increasing rate of Juvenile delinquency and immorality in the society. Counselling is culture specific, and Nigerian counsellors will no doubt find I. N. F. T. productive especially in group counselling among children. Africa's rich cultural heritage must be explored by African counsellors to handle behaviour problems among children. Besides, the current approach to school counselling is preventive and developmental rather 
than curative, \{Adegoke, 2004\}. In this regard, I. N. F. T. will provide a rich store of material for counsellors working in African settings.

\section{References}

Adegoke, A. A. (2004) ed. Counselling Curriculum for Schools in Nigeria. A publication of the Counselling Association of Nigeria. Ilorin: Goshen Print Media Ltd.

Adeoye, E. A. (2000) Alternative to Punishment Procedures in the classroom: a counsellor's Perspective. In Idowu et al. Ed. A guide to teaching practice. Ilorin: Haytee.

Press, P., Coy, B. O. (1988). The Yoruba and Afro-American Trickster: A Contextual Comparison. Presence African, 147: 3.

Mapanje, D., White, L. (1983). Oral Poetry from Africa. Great Britain: Longman.

Miquaii, D., Windahl, S. (1993). Communication models for the study of Mass Communication. New York: Longman.

Okeowo, A. O. (2003). Counselling for Prevention of Social Vices through the use of Folktales. Paper presented at the 27th Annual (CASSON) Conference, University of Ibadan 18th $-22^{\text {nd }}$ August.

Okeowo, A. O. (2006). Development and Efficacy of an Indigenous Nigerian Folktale Therapy for reducing Juvenile Delinquency Among Junior Secondary School Students in Kwara State, unpublished doctoral thesis presented to the Department, of Guidance and Counselling, University of Ilorin.

Sutherland, E. T. (1977) $2^{\text {nd }}$ Impression.The Marriage of Anansewa. African Creative Writers Series. Great Britain: Longman Group Ltd.

Ugorji, O. K. (1991). The Adventures of Tortoise: tales from West Africa. Trenton: Africa World Press.

\section{Author Biography}

Dr. Adeoye Emmanuel Atanda $(\mathrm{PhD})$ is a senior Lecturer at the Counsellor Education Department, University Of Ilorin, Nigeria. Currently he is the postgraduate coordinator of the Department. In 2009, he served as acting Head of Department of Ibrahim Badamasi Babangida University, Lapai, Niger State. His research interests focus on stress and related problems.

Dr. Okeowo, Adegoke Olayinka $(\mathrm{PhD})$ is a Chief Lecturer at the Federal College of Education, Okene, Nigeria. He is a member of the Business Committee of the Academic Board. His research interests focus on adolescent psychology.

Dr. Yusuf, Adeoti Florence $(\mathrm{PhD})$ is a Lecturer at Osun State University, College of Education. She is the College Examination Officer (CEO) and her research interests focus on School Related Problems.

Dr Ogidan Rotimi Joshua (PhD) is the Deputy Director of the Directorate of Counselling Services in the National Open University of Nigeria. He has worked on Prison Inmates and Quality Assurance in higher education. Presently, he is on secondment to the African Council for Distance Education Secretariat in Nairobi, Kenya as Senior Programme Officer. 